\title{
SYAIR AQAID SAEKET SEBAGAI METODE DAKWAH DALAM MENANAMKAN AQIDAH AHLUSSUNNAH WAL JAMAAH AN- NAHDLIYAH
}

\author{
Oleh: \\ Nadrotin Mawaddah, Dita Aulia Rahmah \& Masyhuri \\ Universitas Islam Malang, Indonesia \\ nadrotinmawaddah@gmail.com \\ ditaaulia97@gmail.com \\ masyhuri.makhfudz@unisma.ac.id
}

\begin{abstract}
:
The da'wah method of KHR. Syamsul Arifin and KHR. As'ad Syamsul Arifin in instilling aqidah Ahlussunnah Wal Jama'ah An-Nahdliyah using Syair Aqaid Saeket and how to make it exist untill now are the interesting and necessary topic for this research. With qualitative method that focuses on content analysis and empirical data, the results of the study is concluded as follows: First, Syair Aqaid saeket is a beautiful verse written by two Ulama which contains fifty aqaid, the names of the Prophets, the book of Allah, Malaikat, the pillars of Islam and the pillars of Islamic faith which is a completed-enough summary of aqidah Ahlussunnah Wal Jama'ah An-Nahdliyah. Second, the method of da'wah in this verse is da'wah bi al-qalam and bi al-lisan by using the psychological and cultural approach, namely regional language (Madura). Third, the everlastingness of this verse is supported by several factors; the method of habituation or repetition, spreading by the students, graduates, sympathizers, and several jam'iyah, and also because of the figures of the two authors.
\end{abstract}

Keyword: Aqaid seket, Syair, Metode Dakwah, Aqidah Ahlussunnah Wal Jama'ah.

\section{A. Pendahuluan}

Aqidah merupakan unsur terpenting bagi kehidupan manusia sebagai pokok keimanan seseorang terhadap tuhannya. Oleh sebab itu, jika aqidah goyah sedikit saja, maka segala hal yang berkaitan dengan kehidupan beragama seorang manusia juga akan goyah dan bisa saja terjatuh pada kesesatan. Allah SWT berfirman yang artinya: "Dan apakah orang yang sudah mati lalu Kami hidupkan dan Kami beri dia cahaya yang membuatnya dapat berjalan di tengah-tengah orang banyak, sama dengan 
orang yang berada dalam kegelapan, sehingga dia tidak dapat keluar dari sana? Demikianlah dijadikan terasa indah bagi orang-orang kafir terhadap apa yang mereka kerjakan." 1

Berdasarkan ayat tersebut, tidak adanya keimanan kepada Alla SWT akan membuat seseorang senantiasa dalam kegelapan. Oleh sebab itu, sangat penting bagi setiap manusia memiliki aqidah yang kuat sebagai pondasi keimanan pada Tuhannya. Aqidah yang dianut haruslah sesuai dengan apa yang diajarkan oleh Rasulullah saw secara turun temurun melaui para sahabat, tabi'in dan tabi'it tabi'in dan seterusnya. Hal ini sejalan dengan hadits Nabi;

Nabi Muhammad saw. Memberitahu bahwa: "ummatku akan terpecah menjadi 73 golongan, yang selamat hanya satu, lainnya binasa". Beliau ditanya: "siapa yang selamat?" Beliau menjawab: "Ahlussunnah wal jamaah". ditanya lagi: " siapa ahlussunnah wal jamaah?" beliau menjawab: "yang mengikutiku dan para sahabatku". (HR. Ibnu Majah dan AlTurmudzi).

Berdasar pada hadits tersebut, maka semua golongan dan firqoh Islam yang ada di dunia memiliki penafsiran tersendiri pada konsep ahlussunnah wal jamaah, termasuk di bidang aqidah. Nahdlatul Ulama sebagai organisasi jam'iyah terbesar di Indonesia telah menetapkan dalam masalah Aqidah mengikuti imam Abu hasan Al-Asy'ari dan Imam Abu Mansur Al-Maturudi. ${ }^{2}$ Dengan demikian, warga Nahdiyyin dengan terangterangan dan secara sadar menyatakan dirinya masuk dalam golongan Asya'Ariyah dan Almaturidiyah, sebutan bagi golongan yang mengikuti dua Imam tersebut. Alasannya adalah karena Keduanya merupakan imam besar yang sangat populer di dunia Islam sampai saat ini dan dipandang paling mumpuni dalam bidang aqidah. Keduanya juga memiliki sanad keilmuan yang terpercaya karena bersambung hingga para Sahabat dan Rasulullah SAW.

Di Indonesia, terutama di pesantren-pesantren, Aqidah Ahlussunnah wal jamaah dipelajari dari beberapa kitab klasik berbahasa arab seperti aqidatul awam, mujaz al-kalam, jalaul afham, Nur adhDhalam, dan lain sebagainya. Kitab-kitab tersebut menjadi kitab standar pada mata pelajaran tauhid atau aqidah di pesantren-pesantren di Indonesia. Bahkan di masyarakat jawa dan madura dan pondok-pondok tertentu sifat-sifat tersebut dijadikan sebagai "pujian" atau syair (kalimat pemujaan dengan dilagukan) yang dibaca di mushalla-mushalla sebelum

${ }^{1}$ Q.S Al-An'am :122.

${ }^{2}$ KH. Hasyim Asy'ari. Qonun asasi, (kudus: Menara, 1971). 23. 
melakukan shalat jama'ah. ${ }^{3}$ Salah satu pembahasan di dalamnya adalah Aqaid khomsin atau aqaid lima puluh. Kata Aqoid merupakan bentuk Jama' dari kata Aqidah. Penggunaan bentuk jama' karena berisikan satu bundelan (ikatan) yang jumlahnya 50, yaitu 20 sifat wajib bagi Allah, 20 sifat mustahil bagi Allah, 1 sifat jaiz bagi Allah, 4 sifat wajib bagi Rasul, 4 mustahil bagi Rasul dan 1 sifat jaiz bagi Rasul.

Memahami Aqaid lima puluh ini bukanlah hal yang mudah. Kesulitannya adalah karena materi ini ditulis dalam kitab-kitab berbahasa Arab yang membutuhkan ilmu-ilmu lain untuk bisa membacanya. Selain itu, untuk mendapatkan pemahaman yang tepat dan utuh, tidaklah cukup hanya dengan membaca saja akan tetapi diperlukan bimbingan dari seorang guru. Proses belajar ini mungkin bisa ditempuh oleh para santri namun tidak bagi orang awam atau masyarakat sekitar, terutama bagi mereka yang sudah tidak memiliki kesempatan banyak untuk terus belajar. Oleh sebab itu, kyai-kyai pesantren mencari cara atau metode dakwah yang paling mudah dan efektif. Salah satunya adalah merangkumnya dan menerjemahkan ke bahasa daerah setempat bahkan menggubahnya menjadi lagu atau syair. Ketika masyarakat awam mendengar syair tersebut, mereka lebih mudah memahami konsep aqidah aswaja, tanpa perlu merasa digurui dan diperintah untuk belajar.

Salah satu syair yang populer adalah syair aqaid saeket yang dalam bahasa madura berarti Aqaid lima puluh. Syair ini ditulis oleh KHR. Syamsul Arifin sekitar satu abad yang lalu di Pondok Pesantren Salafiyah Syafi'iyah Sukorejo. Syair ini kemudian disempurnakan oleh putranya KHR. As'ad Syamsul Arifin. Penggunaan bahasa madura ternyata sangat cocok bagi masyarakat sekitar yang notabene juga berbahasa madura. Hingga saat ini, syair tersebut masih terus dibaca bukan hanya di pesantren tersebut, tapi sering terdengar di beberapa mushalla dan masjid di kabupaten Situbondo dan sekitarnya bahkan hingga pulau Madura. Di madrasah-madrasah atau kelas mata pelajaran PAI, ketika pelajaran sifatsifat Allah dan Rasul, bisa dipastikan para siswa menghafal menggunakan irama syair ini.

Pemilihan Metode dakwah melalui syair berbahasa madura dalam menanamkan aqidah Ahlussunnah Wal Jama'ah An-Nahdliyah ternyata sangat diterima dan melekat di tengah masyarakat hingga saat ini. Hal ini membuat peneliti tertarik untuk mengetahui lebih dalam tentang metode dakwah yang digunakan, penyebarannya, hingga bagaimana syair ini

3 Tolhah Hasan. Ahlussunnah wal jama'ah dalam persepsi dan tradisi NU. (Jakarta: Lantabora, 2003), 23.

$124 \mid$ JURNAL LISAN AL-HAL 
dilestarikan. Dengan demikian, tujuan penelitian ini adalah untuk mengetahui 1) Bagaimana Aqidah Ahlussunnah wal jamaah ditulis dalam syair tersebut, 2) Bagaimana metode dakwah yang dilakukan melalui syair ini, dan 3) faktor apa saja yang membuat syair ini lestari hingga saat ini.

\section{B. Metode}

Metode yang digunakan dalam penelitian ini adalah penelitian kualitatif. Penelitan kualitatif adalah penelitian yang menggunakan latar alamiah, dengan maksud menafsirkan fenomena misalnya perilaku, persepsi, motivasi, tindakan dan lain-lain, secara holistik dan dengan cara deskripsi dalam bentuk kata-kata dan bahasa, pada suatu konteks khusus yang alamiah dan dengan memanfaatkan berbagai metode alamiah. ${ }^{4}$

Penelitian yang dilakukan oleh peneliti adalah mengkaji tentang syair aqaid saeket sebagai metode dakwah pada aqidah ahlussunnah wal jamaah an-Nahdliyah. Dimana peneliti menggunakan pendekatan deskriptif kualitatif. Moleong mengatakan bahwa deskriptif kualitatif merupakan penelitian yang berisi akan kutipan-kutipan data untuk memberikan gambaran penayajian laporan yang berasal dari naskah wawancara, catatan lapangan, foto, videotape, dokumen pribadi, catatan atau memo, dan dokumen resmi lainnya. ${ }^{5}$

Dalam penelitian ini, peneiliti mengumpulkan data dengan cara melakukan wawancara (interview) dan dokumentasi. Wawancara digunakan untuk menemukan data empirik dari para alumni dan simpatisan yang ikut serta melestarikan syair aqoid saeket. Sedangkan dokumentasi digunakan untuk mengumpulkan data berupa kajian, buku, dan literatur lain yang membahas aqoid 50 dan syair aqoid saeket ini.

Sedangkan teknik analisis yang digunakan adalah gabungan antara analisis isi dan reduksi data empirik. Analisis isi yang artinya dengan cara menganalisis terhadap suatu teks, mengiterpretasikan gambar, symbol, dan lain sebagainya. ${ }^{6}$ sedangkan reduksi data merupakan teknik analisis data menurut Sirkuler Nasution yang terdiri dari tiga tahap yaitu 1)reduksi data, 2) display data, dan 3) kesimpulan dan verifikasi. ${ }^{7}$ Data

\footnotetext{
2005), 11.

${ }^{4}$ Lexy, J. Moleong, Metodologi Penelitian Kualitatif, (Bandung: Remaja Rosda Karya,

5 Lexy, J. Moleong, Metodologi Penelitian Kualitatif, (Bandung: Remaja Rosda Karya, 2005), 131.

6 Muri Yusuf. Metode Penelitian Kuantitatif, Kualitatif \& Penelitian Gabungan. (Jakarta: Kencana, 2014). 441.

7 Satori, Djam'an dan Aan Komariah. 2012. Metodologi Penelitian Kualitatif. 
yang diperoleh pertama akan dikelompokkan, disederhanakan dan dipilih (reduksi) sesuai dengan konteks penelitian kemudian disusun secara sistematis (display) agar mudah untuk mearik kesimpulan.

Berdasarkan konsep tersebut, dapat diartikan bahwa penelitian ini akan menganalisis isi dari dokumen syair Aqaid Saeket karya KHR. Syamsul Arifin dan KHR As'ad Syamsul Arifin berupa dokumen audio skrip (lirik syair), buku serta artikel yang membahas tentang syair tersebut. Dengan menganalisis dokumen-dokumen tersebut, peneliti mencoba untuk menginterpretasikannya dipadukan dengan data empirik berupa hasil wawancara. Data empirik ini dianalisis dengan cara direduksi dan disusun secara sistematis untuk mendapatkan kesimpulan.

\section{Pembahasan}

1. Pengarang Syair Aqaid Saeket; KHR. Syamsul Arifin dan KHR. As'ad Syamsul Arifin

Syair Aqaid saeket ini ditulis oleh KHR. Syamsul Arifin, Seorang Kyai yang terkenal dengan sosok dan kepribadiannya yang sangat sederhana dan bersahaja. Beliau adalah pendiri sekaligus pengasuh pertama Pondok Pesantren Salafiyah Syafi'iyah Sukorejo Situbondo. KH. R. Syamsul Arifin yang juga di kenal dengan nama Raden Ibrahim, lahir pada tahun 1619 M di desa lancar, kecamatan larangan, kabupaten pamekasan, madura. Beliau merupakan putra dari KH. Ruham dengan Nyai. Nur Sari (Khotijah).

Setelah mengenyam pendidikan dari berbagai pesantren di tanah air dan juga di Makkah, pada tahun 1908 M beliau merantau dari tanah madura ke jawa timur, tepatnya di Situbondo untuk mendirikan sebuah pondok pesantren. Perjalanan mendirikan pesantren ini begitu panjang dan penuh kisah spiritual yang sangat mendalam. Singkat cerita, dengan wasilah petunjuk dari beberapa tokoh dan waliyullah, beliau menemukan lokasi yang tepat, yakni di Suko Beloso yang kemudian dikenal dengan Sukorejo.

Berbeda dari kisah berdirinya podok pesantren lain di tanah jawa yang di bangun di tengah lingkungan masyarakat -baik kampung maupun kota- yang memang sudah ada sebelum pesantren di bangun, lokasi tempat KHR. Syamsul Arifin membangun pesantrean adalah hutan belantara. Beliau membabat hutan tersebut, kemudian mendirikan gubuk,

(Bandung: Alfabeta). 217-220.

126 JURNAL LISAN AL-HAL 
mushalla, hingga pesantren yang kemudian diberi nama Pondok Pesantren Salafiyah Syafi'iyah Sukorejo. Bersamaan dengan perkembangan pesantren, barulah muncul masyarakat sekitar secara berangsur-angsur yang notabene mereka juga merupakan masyarakat asli madura yang merantau ke tanah jawa.

Di pesantren inilah, KHR. Syamsul Arifin menulis syair Aqaid Saeket. Tidak ada yang mengisahkan latar belakang mengapa beliau menulis syair ini. Namun dapat disimpulkan bahasa madura dalam syair ini terkait dengan lingkungan masyarakat di sekitar pondok pesantren tersebut yang mayoritas berbahasa madura. Syair tersebut merupakan bentuk kepedulian dan rasa tanggung jawab beliau untuk mengajarkan aqidah ahlussunnah wal jama'ah baik kepada santri di pesantrennya maupun masyarakat di sekitarnya.

KHR. Azaim Ibrahimy (pengasuh ke-4) bercerita bahwa KHR. Syamsul Arifin menulis syair Aqaid Saeket ini di tabing (dinding berbahan bambu) dari kediaman beliau yang sederhana. Bahkan terhitung sederhana baik ketika zaman itu terlebih lagi di zaman ini. Namun pilihan kesederhanaan beliau inilah yang mengajarkan kekuatan kehidupan di dalam berislam, beriman dan berihsan. ${ }^{8}$

Pada tahun 1951 setelah K.H. Samsul Arifin meninggal, pondok pesantren tersebut dilanjutkan oleh pengasuh kedua yakni putra beliau, KHR. As'ad Syamsul Arifin. Di bawah kepemimpinan Kiai As'ad, Pondok Pesantren Salafiyah Syafi'iyah berkembang semakin pesat, dengan bertambahnya santri hingga mencapai ribuan. Di masa beliau juga mulai dibentuk pendidikan klasikal diniyah seperti Madrasah Ibtidaiyah, Tsanawiyah, dan Aliyah. Kemudian didirikan pula sekolah umum seperti SMP, SMA, dan SMEA hingga mulai merintis perguruan tinggi.

Selain dikenal sebagai kiai atau pengasuh pondok pesantren, beliau juda dikenal sebagai ulama kharismatik sekaligus tokoh Nahdlatul Ulama dengan jabatan terakhir sebagai Dewan Penasihat (Musytasar) Pengurus Besar Nahdlatul Ulama hingga akhir hayatnya. Sebelum NU berdiri, beliau adalah penyampai pesan (Isyarah) yang berupa tongkat disertai ayat al-Qur'an dari KH. Kholil al-Bangkalani untuk KH.Hasyim Asy'ari, yang merupakan cikal bakal berdirinya Nahdlatul Ulama. Selain itu, beliau juga dikenal sebagai salah satu pejuang Indonesia yang ikut berperang melawan penjajah. Oleh karena itu, pada tanggal 9 November

5.

8 Ma'had Aly Situbondo IX. Syarah Aqaid Saeket. (Situbondo: Tanwirul Afkar, 2017), JURNAL LISAN AL-HAL $\mid 127$ 
2016, beliau dinyatakan sebagai Pahlawan Nasional oleh Presiden Joko Widodo.

Kembali pada pembahasan tentang Aqaid saeket, di tangan KHR. As'ad Syair ini yang merupakan khazanah warisan dari ayahandanya, kemudian beliau sempurnakan dengan menambahkan beberapa bait syair. Oleh karena itu, ketika berbicara tentang syair Aqaid saeket, maka tidak akan bisa lepas dari kedua tokoh kharismatik tersebut. Keduanya bukan hanya memiliki ikatan sebagai anak dan orang tua, tapi juga sebagai guru dan murid, serta sebagai penerus estafet perjuangan dakwah untuk menegakkan ajaran Islam Ahlussunnah wal Jamaah.

\section{Syair Aqaid Saeket}

Syair aqaid saeket ini terdiri dari 407 kata; KHR. Syamsul Arifin mengarang 122 kata pertama. Beliau mengawali syair dengan dua kalimat syahadat yang ditulis dalam bahasa madura, sebagai berikut:

"Kaule anyakse'e sobung Pangiran anging Allaah ngaratoni de' alam sadheje. Dzat Settong sefat ben af'al. Kaule anyakse'e Nabi Muhammad Utusan Allaah katurunan Qur'an Hadits lerres ongghu wejib e toro'." (saya bersaksi tiada Tuhan selain Allah SWT Menguasai alam semesta. Dzat, sifat, dan perbuatanNya tunggal. Saya bersaksi Nabi Muhammad SAW utusan Allah swt, menerima wahyu berupa Al-Qur'an dan Al-Hadits, kebenaran yang tidak terbantahkan dan wajib diikuti).

Pada bagian selanjutnya, beliau menulis tentang tentang Aqaid Khomsin (Aqaid lima puluh) yang merupakan cerminan aqidah ahlussunnah wal jama'ah berhaluan Imam Abu Hasan Al-Asya'ari. Baik syair terdiri dari:

1) 20 Sifat wajib Bagi Allah dan 20 sifat Muhal Bagi Allah

Wujud, Qidam, Baqo', Mukholafatuhu lilhawaditsi, Qiyamuhu bii nafsihi, Wahdaniyat, Qudrot, Irodat, Ilmu, Hayat, Sama', Bashor, Kalam, Qodiiron, Muridan, 'Aaliman, ayyan, Sami'an, Bashiiron, Mutakalliman.

Adam, Huduts, Fana', Mumatsalatuhu lil hawaditsi, Ihtiyajuhu bi mujidin, Murokkabun, 'Ajzun, Karohun, Jahlun, Mautun, Shomamun, 'Amaa, Harosun, Ajizun, Karihun, Jaahilun, Mayyitun, Ashomun, A'maa, Abkam.

Wajib ben Muhal. (wajib dan muhal)

2) 1 sifat jaiz bagi Allah

Settong sefat Jaiz abhedhi mungkin adhingghel mungkin deliluhe musyahadah Wajib Iman oreng Mukallaf. (Allah hanya memiliki satu sifat jaiz yaitu boleh melakukan atau meninggalkan sesuatu yang mungkin terjadi)

$128 \mid$ JURNAL LISAN AL-HAL 
3) 4 sifat wajib bagi para Rasul

Siddiq, Amanat, Tabligh, Fatonatun

wajib e akal sengaghungi Nabi Utusan ka teptepan deri Allaah. (Sifat yang wajib -secara akal - dimiliki oleh nabi dan rasul)

4) 4 Sifat Muhal Bagi Para Rasul

Kidzib, Khiyanat, Kitman, Baladatun

muhal e akal.(muhal -secara akal- dimiliki oleh nabi dan Rasul)

5) 1 Sifat Jaiz bagi para Rasul

Jawazuhu a'rodl khofifah. (Sifat jawaz/jaiz bagi para nabi dan Rasul adalah a'radl khafifah (sifat-sifat kemanusiaan yang ringan)

ampon ghenna' saeket Aqoid. (maka telah lengkap aqoid yang 50).

Bait syair setelahnya merupakan karangan dari KHR. As'ad Syamsul Arifin yang ditambahkan untuk menyempurnakan syair Aqaid Saeket ini. Bait yang beliau tulis terdiri dari: Kaule wejib Iman Nabi Utusan saghemi' bennya'na ketab empa' ampon ka sebbhut delem Qur'an bilenganna. (Saya wajib iman kepada para Rasul yang berjumlah 25, begitu pula wajib mengimani 4 kitab yang diturunkan kepada para utusan yang telah disebutkan rincian nama-namanya dalam Al-Qur'an).

1) 25 Rasul

Adam, Idris, Nuhun, Huudun, Shaalihun, Ibrohim, Lutun, Ismail, Ishaq, Ya'qub, Yusuf, Ayyub, Syuib, Harun, Musa, Yasa', Dzulkifli, Daud, Sulaiman, Ilyas, Yunus, Zakariya, Yahya, Isa, Nabi toha di budinna (Nabi Toha yang terakhir).

2) 4 Kitab Suci

Taurot ka Nabi Musa. Zabur se toron ka Nabi Daud. Ketab Injil ka Nabi Isa. Nabi Ahmad kaparengan Qur'an. (Kitab Taurat diturunkan pada Nabi Musa As. Kitab Zabur diturunkan pada Nabi Daud As. Kitab Injil diturunkan pada Nabi Isa As. Sementara Al-Qur'an diturunkan pada Nabi Muhammad SAW). 3) 10 Malaikat dan tugasnya

Jibril se ngibe Wahyu.

Mikail muwakkal adhu'um Arzaq pade milo sadheje Makhluq raje keni' sobung se ceccer

Azroil ngala'an arwah.

Isrofil muwakkal billauhil mahfudh

Mungkar Nakir mantre kobhuren tako' ongghu bile mareksa.

Rokib, Atit malakan kanan kacer pade e jege, jhube' becce' pade e toles siang malem ghente ghente.

Naraka jege'en Malik, seddhi bhei tak mangghi bhunga se dereka capbhur ka delem, oreng kafir neng be bebe.

Suarghe jege'en Ridlwan bhunga bhei tak mangghi sossa Islam Mukmin

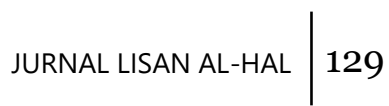


pade masok bidedderi jhudhuwenna Wildan se ngaladhini ka bhungaan sobung bhendhingan nikmat raje nangale Allaah e suarghe salanjhengnga.

Artinya :

Malaikat Jibril pembawa wahyu

Mikail penabur rezeki kepada semua makhluk tanpa terkecuali

Azroil pencabut nyawa

Isrofil penjaga lauhul makhfudz

Munkar nakir malaikat penjaga kuburan yang menakutkan ketika bertanya

Rokib dan Atit dua malaikat penjaga kanan dan kiri kemudian mencatat amal baik dan buruk bergantian siang dan malam

Neraka dijaga oleh malaikat Malik, kesedihan yang selalu dirasakan di dalamnya tidak ada kebahagiaan di sana, orang yang durhaka dilemparkan ke dalamnya, orang kafir yang paling bawah.

Surga dijaga oleh malaikat Ridwan, kebahagiaan yang selalu dirasakan di dalamnya tidak ada kesedihan, muslim mukmin yang masuk di dalamnya, bidadari pendampingnya, wildan yang melayani, kebahagiaan yang tak ada bandingannya, kenikmatan terbesar adalah melihat kebesaran Allah, di surga selamanya.

4) Rukun Islam

Rukunna Islam lema'

Syahedet due' estoaghi Dhohir Batin pade pa kokoh siang malem Imanaghi

Sholat se lema bekto syarat rukun wejib pa ghenna' Ikhlas Khusyu' e delem ate Mughe Mughe e maqbule

Zakat harta ben bhedhen parengaghi de' Faqir Miskin bellu' macem olle narema jhube' ongghu oreng se cerre'

Puasa e bulen Romadlon poma poma jhe' entengaghi dhusa raje lamun $e$ dhingghel Ghuste Allaah ce' Dhukana

Hajji de' baitullaah lamon cokop ongkos jhelenna entar mule ben se edhina, ate ate syarat rukunna.

Rukun Islam ada 5:

Pertama 2 syahadat, teguhkan dalam hati lahir dan batin, siang malam tetap beriman.

Kedua, shalat 5 waktu, dengan memenuhi syarat dan rukunnya serta dilakukan dengan khusyu'. semoga diqobul oleh Allah swt.

Ketiga, zakat harta (mal) dan zakat badan (fitrah) berikan pada faqir miskin, ada 8 orang yang berhak menerima, sungguh buruk orang yang kikir.

Keempat, puasa di bulan Ramadhan, hati-hati jangan dientengkan, dosa

$130 \mid$ JURNAL LISAN AL-HAL 
besar jika ditinggalkan dan Allah swt sangat murka.

Kelima, haji ke baitullah jika cukup biaya berangkat dan pulang dan keluarga yang ditinggal di rumah, hati-hati tunaikanlah syarat dan rukunnya.

5) Rukun Iman

Rukunna Iman ennem; Iman de' Allaah de' Malaikat Rosulillaah Kitabillaah yaumil akhir dhina qiyamat rukun se kapeng ennem pasti bheghus ben paste jhube' deri Allaah sadhejena lamun mungker kafer ongghu. (Rukun iman ada 6; Iman kepada Allah swt., malaikat, Rasulullah, Kitabullah, hari akhir/ hari qiyamat. Dan yang keenam, ketentuan baik dan buruk semuanya dari Allah swt. Sungguh tergolong orang kafir bila mengingkari).

6) Ditutup dengan sebuah nasehat / mau'idhoh hasanah

Kaule anyu'una ongghu tore abhekte de' Ghuste Allaah taretan kaule se ghi' odi' Alam dhunnya ampon Akhir. (Saya mohon wahai saudaraku yang masih hidup, ayo berbakti kepada Allah swt karena alam semesta akan segera berakhir).

Di tinjau dari iramanya, syair Aqaid Saeket memiliki irama tersendiri yang hingga saat ini tidak pernah diubah dari aslinya. Secara teori kebahasaan, syair ini keluar dari pakem kepenulisan syair pada umumnya. Biasanya syair jaman dulu ditulis dengan memainkan alur yang linear dan lurus dengan rima aa aa, aa bb dan seterusnya. ${ }^{9}$ Tapi syair ini tidak menggunakannya. Namun hal ini bukan hal baru, banyak syair berbahasa daerah yang juga tidak mengikuti pakem tersebut. Salah satunya adalah syair populer karya Sunan Kalijaga, lir ilir. Coba perhatikan potongan bait lir-ilir berikut:

Cah angon penekno blimbing kuwi

Lunyu lunyu penekno kanggo mbasuh dodotiro.

Keindahan syair aqaid saeket ini membuat para pengamat syair, khususnya para penyair madura sangat kagum. Salah satunya adalah KH. Zawawi Imron, seorang penyair terkenal yang berdarah asli madura. Beliau menyapaikan bahwa syair Aqaid Saeket yang digubah oleh Kiai Syamsul dan Kiai As'ad merupakan upaya kedua kiai tersebut untuk memudahkan pemahaman masyarakat Madura tentang akidah ahlussunnah wal jamaah. Di lain pihak, masyarakat Madura membutuhkan kehadiran syair tersebut agar mereka selamat. Sebab dalam masyarakat Madura terdapat pepatah: "abhental syahadat, asaphok iman, apajhung rahmate Allah maleh paste selamet" (berbantal syahadat, berselimut iman, berpayung rahmat Allah swt, agar selamat). Di sinilah terdapat

${ }_{9}^{9}$ Goenawan Mohamad. Puisi dan Antipuisi. (Jakarta: Tempo Publishing, 2011), 57. 
perjumpaan antara tradisi Madura dan tradisi pesantren. ${ }^{\mathbf{1 0}}$ Ungkapan dari seorang penyair yang asli dari madura ini tentunya semakin mengukuhkan bahwa eksistensi dan keindahan syair ini diakui bukan hanya oleh masyarakat sekitar tapi juga bagi pemilik asli kebudayaan madura itu sendiri.

Untuk memperdalam tentang kaindahan syair ini, bisa dilihat dari segi harmonisasi bahasanya. Sebagaimana yang dijelaskan sebelumnya bahwa syair ini sebenarnya ditulis oleh dua orang kiai. Namun jika dibaca, seolah-oleh ditulis oleh satu orang saja karena dari awal hingga akhir memiliki pola bahasa yang sama. Misalnya di awal syair, KHR. Syamsul Arifin menulis:

"kaule anyakse e sobung pangiran anging Allah" (saya bersaksi tidak ada tuhan selain Allah).

Sedangkan tambahan syair dari KHR. As'ad sebagai berikut:

"Kaule wejib iman nabi utusan sagemi' benynya'na.." (saya wajib beriman bahwa nabi utusan ada dua puluh lima) dan pada akhir syair "kaule nyu'una ongghu, tore abekte de' Guste Allah taretan kaule se ghi' odik..." (saya sungguh memohon mari berbakti kepada Allah swt. wahai saudaraku yang masih hidup).

Pengulangan kata "kaule" di sinilah yang membuat bait-bait tersebut terdengar senada. Menurut Kiai Azaim, kata "kauleh" (bahasa madura yang berarti saya) memiliki arti yang khusus. Kata ini diletakkah di awal kalimat karena berarti "hamba", harus merendahkan hati, harus menghambakan diri terlebih dahulu baru kemudian dapat meneruskan dengan kata berikutnya, anyakse e (menyaksikan). ${ }^{11}$

Ach. Muhyiddin Khatib, dalam pengantar buku syarah Aqaid saeket juga menyebutkan bahwa keselarasan bahasa dari kedua tokoh tersebut mirip dengan kitab Tafsir Jalalain, yang juga dikarang oleh dua imam, yaitu Imam Jalaluddin Al-Mahally dan Imam Jalaluddin As-Suyuthi. Kalau dibaca, maka hampir tidak ditemukan perbedaan dalam susunan kata, retorika dan diksi kata yang digunakan. Andai saja dalam pembukaan kitab ini tidak dijelaskan bahwa dikarang oleh dua ulama, maka pasti diduga bahwa kitab ini dikarang oleh satu ulama saja. Hal ini tidak mungkin terjadi jika di antara keduanya tidak ada sambungan rohani. Sebagaimana yang juga

\footnotetext{
${ }^{10} \underline{\mathrm{http}}: / /$ sukorejo.com/2018/03/14/Syair-Aqaid-Saeket-Perjumpaan-BudayaPesantren-dan-Madura.html

11 Ceramah KHR. Ahmad Azaim Ibrahimy dalam bedah buku Aqaid Saeket. http://sukorejo.com/2018/03/14/Syair-Aqaid-Saeket-Perjumpaan-Budaya-Pesantrendan-Madura.html $132 \mid$ JURNAL LISAN AL-HAL
} 
terjadi pada syair Aqaid Saeket, keselarasan bahasa kedua pengarang tidak mungkin terjadi jika seandainya tidak ada sambungan rohani yang kuat di antara keduanya. ${ }^{12}$

Keselarasan kedua tokoh ini juga dapat dilihat dari keseriusan dalam menanamkan aqidah Ahlussunnah waljamaah melalui syair ini. KHR Syamsul Arifin menuliskan aqaid lima puluh pada bait-bait awal, yang mana aqaid lima puluh merupakan salah satu komponen penting dalam Aqidah aswaja Asy'ariyah. Beberapa tahun kemudian KHR. As'ad menyempurnakan syair ini menjadi lebih lengkap yaitu menampah namanama nabi, kitab-kitab Allah, nama malaikat, rukun islam dan rukun iman. Setelah disempurnakan, syair ini menjadi lebih lengkap menyajikan satu paket kaidah-kaidah aqidah Aswaja yang harus dihafal, dipahami dan ditanamkan dengan kuat sebagai pondasi keimanan. Keberadaan syair ini kemudian menjadi solusi agar masyarakat awam tidak perlu membaca semua kitab klasik berbahasa Arab untuk mengenal Aqidah Aswaja.

\section{Metode Dakwah Dalam Syair Aqaid Saeket}

Dakwah merupakan salah satu kewajiban yang harus dilaksanakan untuk menyebarkan dan menankan nilai-nilai Agama di masyarakat. Salah satu yang sangat penting untuk dalam kehidupan beragama adalah Aqidah karena tanpa aqidah, ibadah seseorang tidaklah bernilai di hadapan Allah swt. ${ }^{13}$ Bahkan seseorang yang tidak memiliki pegangan aqidah yang kuat, kehidupannya akan senantiasa dalam kegelapan. Oleh sebab itu, meletakkan aqidah sebagai salah satu materi dakwah menjadi sangat penting.

Jika ditindau dari segi jenis metode dakwah yang digunakan. Dakwah melalui syair pada dasarnya termasuk dalam kategori da'wah $b i$ Al-Qalam, yaitu dakwah melalui tulisan yang dilakukan dengan keahlian menulis di surat kabar, majalah, buku, maupun dan lain sebagainya. ${ }^{14} \mathrm{Hal}$ ini karena syair tersebut ditulis oleh seorang pengarang. Tidak akan mungkin menghasilkan syair yang indah dan sarat makna, jika pengarang tidak punya keahlian menulis. Sebagai mana yang dibahas sebelumnya bahwa nyatanya syair Aqaid saeket ini sangat indah. Bahkan walaupun ditulis oleh dua orang pengarang, keindahan tiap baitnya tetap selaras dan harmonis. Hal ini yang sangat dikagumi oleh para pengamat santra bahkan

12 Ma'had Aly Situbondo IX. Syarah Aqaid Saeket. (Situbondo: Tanwirul Afkar, 2017), 10.

13 Sayyid sabiq. Aqidah Islam, (Bandung : Al-Ikhlas, 2002), 35.

14 Drs. Samsul Munir Amin, M.A. Ilmu Dakwah. (Amzah Jakarta 2009) 11.

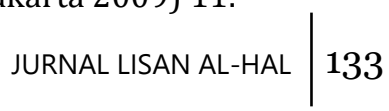


hingga saat ini.

Selain sebagai dakwah bi al-qalam, sejak saat syair ini dibacakan di mushalla satu abad yang lalu, disebarkan dan terus dilestarikan oleh banyak pihak, maka syair ini juga merupakan dakwah bi al-lisan. Dakwah bi al-lisan adalah penyampaian informasi atau materi dakwah melalui lisan. ${ }^{15}$ Menurut Faizah dan Efendi, dalam menyampaikan dakwah atau bersyiar, ada beberapa faktor yang harus diperharikan, yaitu 1) $d a^{\prime} i$ atau pelaksana dakwah, 2) $m a^{\prime} d u$ atau orang yang menjadi obyek dakwah, 3) meteri dakwah, 4) lingkungan dakwah, dan 5) Metode dakwah. ${ }^{16}$ Untuk menentukan materi dan metode dakwah, seorang $d a^{\prime} i$ harus memperhatikan faktor karakteristik $m a^{\prime} d u$ dan lingkungannya. Faktor $m a^{\prime} d u$ dan lingkungannya ini secara spesifik dapat dikaji melalui dua pendekatan, yaitu psikologis dan juga budaya. ${ }^{17}$

Dari sisi psikologis, dapat dilihat bahwa kedua pengarang syair ini sangat memperhatikan karakteristik $m a^{\prime} d u$-nya, yaitu masyarakat sekitar yang notabene masih awam dan tidak memiliki bnyak kesempatan untuk belajar setiap detail ilmu-ilmu agama. Mereka memiliki banyak kesibukan lain yang menjadi kendala seperti, mencari nafkah dan mengurus rumah tangga. Pemilihan metode berupa syair menjadi sangat tepat karena dengan mudah syair ini dibacakan oleh para santri di mushalla dengan sebelum dan seusai shalat berjamaah. Seiring berkembangnya zaman, adanya pengeras suara membuat masyarakat sekitar yang mendengar melalui pengeras suara juga akan menikmatinya dan tanpa sadar mempelajari materi aqidah dalam syair tersebut.

Satria dan Mohamed mengkaji dalam artikelnya bahwa syair atau nasyid merupakan metode yang baik untuk berdakwah karena saat mendengarkan lagu, $m a^{\prime} d u$ tidak akan merasa diperintah ataupun dipaksa untuk mendengar namun secara perlahan nilai dalam lagu akan masuk ke dalam hati dan pikiran mereka. ${ }^{18}$ Teori ini juga terbukti pada syair ini. Hasil wawancara dengan para alumni yang ikut serta menyebarkan dan melestarikan syair ini, mereka menceritakkan bahwa masyarakat awam yang mendengar syair ini sangat senang dan sangat menikmati. terutama ketika sampai pada akhir syair Kaule anyu'una ongghu tore abhekte de' Ghuste Allaah taretan kaule se ghi' odi' Alam dhunnya ampon Akhir. (Saya

15 Drs. Samsul Munir Amin, M.A. Ilmu Dakwah. (Amzah Jakarta 2009), 11.

16 Faizah. Psikologi Dakwah. Jakarta: Kencana, 2018),137.

${ }^{17}$ Faizah. Psikologi Dakwah. Jakarta: Kencana, 2018), 32.

18 Satria, Eri. Mohamed, Roslan. Analisis terhadap peranan nasyid dalam dakwah, Islam Futura. Vol 16, 2017. 239.

$134 \mid$ JURNAL LISAN AL-HAL 
mohon wahai saudaraku yang masih hidup, ayo berbakti kepada Allah swt karena alam semesta akan segera berakhir), hati mereka benar-benar tersentuh.

Selain pendekatan psikologis, syair ini juga memiliki pendekatan kultur atau budaya. Salah satu komponen dalam budaya adalah bahasa daerah. KHR. Syamsul Arifin dan KHR. As'ad Syamsul Arifin menulis syair ini tentunya sangat memperhatikan $m a^{\prime} d u$ atau masyarakat yang menjadi sasaran dari syair ini. Di lihat dari budayanya, masyarakat pondok pesantren Salafiyah Syafi'iyah ini notabene berbahasa dan berkultur madura, maka pemilihan bahasa madura dalam syair ini menjadi sangat tepat bagi mereka. Dengan demikian, mereka bisa memahami aqidah melalui syair ini tanpa perlu mengkasi satu persatu kitab-kitab klasik berbahasa Arab.

Hal lain yang peneliti temukan adalah bahwa syair ini sebenarnya dibarengi dengan kitab bernama Asas Al-Muttaqin yang juga ditulis oleh KHR. Syamsul Arifin. KIitab ini juga berbahasa Arab yang di dalamnya ada penjelasan rinci tentang aqaid saeket. Jika dalam syair bagian sifat-sifat Allah dan Rasul itu hanya berbahasa arab tanpa arti, maka penejasannya ada dalam kitab Asas Al-Muttaqin. ${ }^{19}$ Jika kemudian ada yang berargumen bahwa syair Aqaid Saeket ini terlalu singkat dan masih sulit karena masih ada bahasa Arab di dalamnya, maka jawabannya adalah kitab tersebut. Bahasa yang digunakan juga bahasa madura sehingga jika kitab ini dibacakan di hadapan masyarakat awam, masih tergolong mudah untuk dipahami.

Berdarkan hasil analisis di atas, dapat ditarik kesimpulan bahwa syair Aqaid saeket ini merupakan syair yang ditulis dan disebarkan menggunakan metode dakwah bi al-qalam dan juga bi al-lisan. Selain itu dari segi pendekatannya, syair ini memiliki dua pendekatan, yaitu pendekata psikologis dan juga kultural, yaitu bahasa daerah (madura).

\section{Faktor Pendukung Kelestarian Syair Aqaid Saeket}

Sebagaimana yang telah diungkap sebelumnya bahwa syair ini ditulis oleh pengasuh pertama Pondok Pesantren Salafiyah syafi'iyah Sukorejo. Pondok pesanteren ini sudah berumur lebih dari satu abad. Berarti syair ini pun ditulis sekitar satu abad yang lalu dan hingga saat ini masih dibaca dan dilestarikan. Inilah yang membuat peneliti mengkaji lebih dalam faktor apa saja yang mendukung kelestarian syair ini. Faktorfaktor yang ditemukan adalah sebagai berikut:

${ }^{19}$ KHR. Syamsul Arifin. Asas Al-Muttaqin. (Situbondo: Asy-Syarif, cet. 2005) 
1) Metode dakwah yang sederhana namun terus dilestarikan

Metode yang digunakan sejak dulu adalah pembiasaan. Setiap malam ribuan santri menjelang salat isya' membaca syair ini secara bersamaah di masjid Jamik Pondok Pesantren Salafiyah Syafi'iyah Sukorejo. Salah satu pengurus pesantren memimpin bacaaan melalui pengeras suara yang cukup luas jangkauannya sehingga hampir seluruh area pondok dan masyarakat sekitar dapat mendengarnya. Itu sudah dilakukan bertahun-tahun lamanya dan bisa jadi itu akan terus dibaca selama-lamanya.

Menurut pengakuan para alumni yang sudah lama lulus dari pesantren, ketika mendengar syair ini baik dari mushalla-mushalla di daerahnya maupun dari akun media sosial yang meupload audio syair ini, hati mereka tersentuh karena syair ini mengingatkan pada suasana saat mereka masih di pondok. Hal ini karena mereka sudah sangat terbiasa setiap hari saat isya' menbaca dan mendengarkan syair ini sehingga memori tentang syair ini akan selalu melekat di hati dan sanubari mereka.

1. Peran Santri, Alumni dan simpatisan

Dari tahun ke tahun semenjak pesantren ini berdiri, jumlah santri semakin meningkat hingga ribuan. Angka ribuan itu adalah jumlah santri yang sedang berdomisili di dalam pondok pada saat ini. Tapi jika menghitung jumlah alumni dari awal berdiri hingga sau abad usia pesantren saat ini, maka belum ada angka yang pasti. Para alumni ini setelah lulus dan kemudian berperan di masyarakat, misalnya menjadi guru ngaji, guru agama, tokoh masyarakat, bahkan ada yang memiliki pesantren atau lembaga pendidikan. Sebagian besar dari mereka yang tentunya sangat terkesan dengan syair ini dengan senang hati menyebarkannya melalui mushalla-mushalla, forum pengajian, sekolah, madrasah bahkan pesantrennya. Di lembaga formal, jika alumni pondok pesantren ini menjadi guru Agama atau aqidah akhlak misalnya, maka bisa dipastikan saat mengajarkan sifat-sifat Allah dan RasulNya, senandung irama dari syair inilah yang akan mereka gunakan untuk memudahkan siswa menghafal Aqaid lima puluh. Tidak menutup kemungkinan, santri mushalla, siswa ataupun santri yang diajarkan aqidah dengan syair ini akan terus mengingat bahkan mengajarkannya kembali kepada orang lain. Dengan demikian, syair ini menjadi metode dakwah yang terus diwariskan dari dari generasi ke generasi.

Pada 5 tahun terakhir, syair ini menjadi semakin terkenal karena mahasantri Ma'had Aly PP. Salafiyah Syafi'iyah angkatan IX menulis buku "Syarah Aqaid Saeket" dalam bahasa Indonesia. Buku ini mengupas tuntas

136 JURNAL LISAN AL-HAL 
isi syair ini secara lengkap dengan dalil aqli dan naqli-nya. Setelah itu, dilakukan acara bedah buku yang dihadiri oleh beberapa sastrawan terkenal seperti KH. Zawawi Imron. Kesimpulan dalam dalam acara tersebut bahwa syair ini adalah perjumpaan budaya pesantren dan madura, dan buku tersebut merupakan persembahan indah dari santri kepada gurunya. ${ }^{20}$

Semenjak acara tersebut, syair ini semakin terkenal bahkan di kalangan mereka yang bukan alumni. Syair ini juga disenandungkan oleh beberapa Jam'iyah shalawat dengan massa yang besar seperti Jam'iyah Shalawat Bhenning yang dipimpin oleh KHR. Ach. Azaim Ibrahimy (cucu KHR. As'ad) dan Jam'iyah Shabab (putra ke-2 KHR. As'ad) dan juga beberapa jam'iyah kecil yang dibentuk oleh para alumni dan simpatisan.

2) Ketokohan pengarang

Syair ini akan selalu dikenang di hati masyarakat bukan hanya karena kaindahannya tapi juga karena mengenang figur kedua pengarang yang merupakan tokoh ulama kharismatik, guru yang dirindukan, dan teladan bagi ummat. Oleh sebab itu, tidak heran kalau syair ini terus dibaca dan disebarkan. Selayaknya karya-karya lain seperti lir ilir, tombo ati yang ditulis oleh waliyullah Sunan Kalijaga, seperti juga barzanji, diba yang senantiasa disenandungkan berpuluh-puluh tahun bahkan ratusan tahun. Bisa jadi hal ini juga akan terjadi pada syair Aqaid Saeket.

\section{Simpulan}

Bedasarkan data dan analisisnya, peneliti membuat kesimpulan sebagai berikut: Pertama, Syair Aqaid saeket adalah syair indah karya dua tokoh Ulama yang di dalamnya berisi aqaid lima puluh, nama-nama Nabi, kitab Allah, malaikat, rukun Islam dan rukun Iman yang merupakan ringkasan cukup lengkap dan dapat merepresentasikan ajaran Aqidah Ahlussunnah wal jamaah An-Nahdliyah. Kedua, Metode dakwah dalam syair ini adalah dakwah bi al-qalam sekaligus bi al-lisan dengan menggunakan pendekatan psikologis dan kultural yaitu bahasa daerah (Madura). Ketiga, Kelestarian syair ini didukung oleh beberapa faktor, yaitu a) metode dakwah berupa pembiasaan yang terus dilestarikan dengan cara dibacakan secara rutin sebelum jamaah shalat isya', b) penyebaran oleh para santri, alumni, simpatisan di musalla, madrasah

${ }^{20}$ Syair Aqaid saeket; perjuampaan budaya pesantren dan Madura. http://sukorejo.com/2018/03/14/Syair-Aqaid-Saeket-Perjumpaan-Budaya-Pesantrendan-Madura.html. 
hingga sekolah dan juga disenandungkan di beberapa jam'iyah shalawat, dan c) dari faktor ketokohan kedua pengarang syair ini.

\section{DAFTAR PUSTAKA}

Arifin, Syamsul. Asas Al-Muttaqin. Situbondo: Asy-Syarif. 2005.

Aziz, Moh. Ali. Ilmu Dakwah. Jakarta: Kencana. 2019.

Mahasantri Ma'had Aly Situbondo IX. Syarah Aqaid Saeket. Situbondo: Tanwirul Afkar. 2018.

Muzaki, A. Kesusastraan Arab (Pengantar Teori dan Terapan). Jakarta: ArRuzz Media. 2006.

Pradopo, R.D. Pengkajian Puisi: Analisis Strata Norma dan Analisi Struktural dan Semiotik. Jakarta: Universitas Indonesia. 2005.

Andriani, T. Revitalisasi naskah Syair: Sebuah Solusi dalam Pengembangan Kreativitas Mahasiswa untuk Mencintai Budaya Lokal. 2015.

Departemmen Pendidikan dan kebudayaan. Kamus Besar Bahasa Indonesia. Jakarta: Balai Pustaka. 1990.

Enjang dan Aliyuddin. Dasar-Dasar Ilmu Dakwah. Bandung: Widya Padjajaran. 2009.

Amin, Samsun Munir . Ilmu Dakwah. Jakarta: Amzah. 2009.

Sabiq, Sayyid. Aqidah Islam, Bandung : Al-Ikhlas. 2002.

Hameed, Hakeem A. Aspek-aspek Pokok Agama Islam, terj. Ruslan Shiddieq, Jakarta: Dunia Pustaka Jaya. 1983.

Asy'ari, Hasyim. Qonun asasi, Nahdlatul Ulama. Kudus: Menara. 1969.

Pengertian

Ilmu

Aqaid. https://islam.nu.or.id/post/read/40286/pengertian-ilmuaqoid.

Hasan, Thollhah. Ahlussunnah wal jama'ah dalam persepsi dan tradisi NU. Jakarta: Lantabora. 2015.

Mohamad, Goenawan. Puisi dan Antipuisi. Jakarta: Tempo Publishing. 2011.

Moleong, Lexy J. Metodologi Penelitian Kualitatif. Bandung: Remaja Rosdakarya. 2013.

Musyafiq, A. Aqaid 50 versus Aqaid 48 (kajian Kitab UMM Barahin di Pesantren Salaf. 2013.

http://sukorejo.com/2018/03/14/Syair-Aqaid-Saeket-Perjumpaan-

Budaya-Pesantren-dan-Madura.html

Satori, Djam'an dan Aan Komariah. Metodologi Penelitian Kualitatif.

$138 \mid$ JURNAL LISAN AL-HAL 
Bandung: Alfabeta. 2012.

Syihab, H.Z.A. Akidah ahlus sunnah, Jakarta : Bumi aksara. 1998.

Yusuf, Muri. Metode Penelitian Kuantitatif, Kualitatif \& Penelitian Gabungan. Jakarta: Kencana, 2014. 